\title{
Tempoverschillen in het nieuwe opleiden
}

Er komt steeds meer vaart in de modernisering van de medisch specialistenopleiding. Het Kaderbesluit van het CCMS (Centraal College Medische Specialismen) uit 2005 is al weer aan vernieuwing toe en het merendeel van de nieuwe competentiegerichte opleidingsplannen voor de verschillende specialismen ligt klaar om geïmplementeerd te worden. Teneinde de modernisering daadwerkelijk te borgen zal het nieuwe Kaderbesluit een uitgebreide kwaliteitsparagraaf bevatten. De afgelopen maand heeft de commissie Scherpbier op verzoek van het CBOG (College voor de Beroepen en Opleidingen in de Gezondheidszorg) een studie gepubliceerd over kwaliteitsindicatoren in de specialistenopleiding. ${ }^{1}$ Het is een uitgebalanceerd rapport geworden met een keur aan nuttige instrumenten om mee aan de slag te gaan. We moeten ons daarbij goed realiseren dat het hele innovatietraject een tienjarenproject is. We zijn nog niet eens halverwege deze periode, en haast zou wel eens contraproductief kunnen werken.

In de specialistenopleiding hebben we te maken met allerlei spelers: artsen in opleiding tot specialist (aios), supervisoren, opleiders, paramedici, verpleegkundigen en patiënten, instellingen en natuurlijk de overheid. Elke partij heeft hier zo haar eigen belangen. Lang niet iedereen loopt in de pas, ook het tempo verschilt. Als je op een opleidingsbijeenkomst bent, zoals het recente CBOG-symposium, kom je voor het merendeel enthousiaste voorlopers tegen. Natuurlijk zijn ook daar kritische geluiden te horen. Belangrijker is echter te beseffen dat vele collegae er nog steeds niets van weten of willen weten of sceptisch zijn. Ook hier is haastige spoed zelden goed.

Daarom is het belangrijk als enthousiastelingen in de kopgroep voeling te houden met de stemming in het grote peloton. Het artikel van Stegeman in dit nummer van ons tijdschrift geeft hiervan enkele voorbeelden uit de dagelijkse opleidingspraktijk. In dat verband is het ook nuttig te volgen wat over medisch onderwijs in de algemene medische bladen staat. Zo stond in het Nederlands Tijdschrift voor Geneeskunde recent een fraai overzicht over het geven van feedback in de medische opleiding. ${ }^{2}$ Zoals Stegeman aangeeft moeten we ons echter wel realiseren dat niet alleen de aios maar ook de supervisoren vaak heel andere verwachtingen van feedback hebben. Ook over het klassieke opleidingsmodel, het rolmodel, de voorbeeldfunctie, blijken op de werkvloer soms totaal verschillende opvattingen te bestaan. Een recent artikel in het British Medical Journal toont daarnaast aan dat aios vaak een dubbele agenda hebben bij het vragen om feedback. ${ }^{3}$ Zij zijn geneigd feedback te mijden als er een potentieel gevaar is dat zij daarmee hun geloofwaardigheid naar de supervisor en dus hun beoordeling kunnen ondermijnen. Kortom er bestaan tal van valkuilen waarmee men als opleider/supervisor maar ook als aios rekening dient te houden.

Innovatie van de opleiding is inhoudelijk gezien dus een plan voor de lange termijn. Velen, ook zij die thans op hun eigen manier een waardevolle bijdrage leveren aan de opleiding, moeten nog overtuigd worden 
van het nut en geïnstrueerd worden over de vernieuwing. In de logistieke regelgeving daarentegen gaan de veranderingen weer heel snel. De spelregels rond de toewijzing van opleidingsplaatsen uit het opleidingsfonds worden opnieuw aangepast. Waren we er net aan gewend dat de kwaliteitsindicatoren hiervoor in beeld kwamen, nu lijken die al weer van de baan. Aios krijgen komend jaar de mogelijkheid zelf hun opleidingstraject, dus hun keuze voor een opleider en een instelling, te bepalen en jaarlijks bij te stellen. Dat was al toegestaan voor de zogenoemde vooropleiders (in de eerste jaren interne geneeskunde en heelkunde voorafgaande aan de verdere deelspecialisatie), nu laat men ook de laatste twee jaar van de opleiding voor verdere verdieping in aandachtsgebieden/profielen van enkele grote specialismen vrij.

Opleidingen zullen zich in de etalage moeten zetten, aios kunnen dan vrij kiezen. Het idee van het etalagemodel komt uit onze beroepsgroep zelf, niet verdacht dus, zou je zeggen. De minister, de subsidiegever, lijkt er ook content mee te zijn. De opleiders zullen moeten uitstralen, en vervolgens waarmaken, dat hun opleiding de beste is. Het zal de transparantie in de medische opleiding ongetwijfeld vergroten. We moeten er van uitgaan dat de aios er verstandig mee omgaan en inderdaad kiezen voor de kwaliteit van hun opleiding, dus voor de kwaliteit van hun eigen toekomst.

Paul Stuyt

\section{Literatuur}

1. Scherpbier AJJA et al. Eindrapportage projectgroep kwaliteitsindicatoren. Rapport CBOG 2009 via www.cbog.nl [bezocht op 2 maart 2009].

2. Brand PLP, Boendermaker PM. Feedback geven: cruciale vaardigheid in de medische opleiding. Ned Tijdschr Geneeskd. 2009;153:b141.

3. Kennedy TJT, Regehr G, Baker GR, Lingard L. Preserving professional credibility: grounded theory study of medical trainees' requests for clinical support. BMJ 2009; 338:b128. 